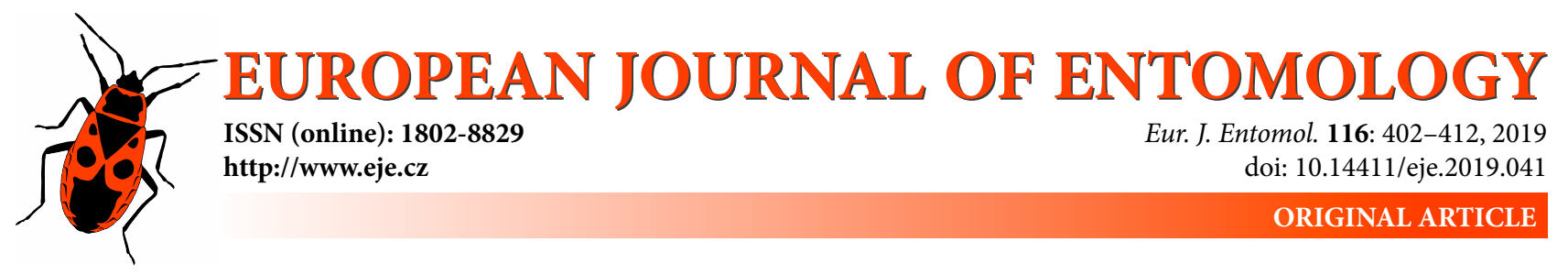

\title{
Screening for stable internal reference genes for quantitative PCR analysis of Wolbachia-host interactions in whitefly Bemisia tabaci (Homoptera: Aleyrodidae)
}

\author{
XIN-CHAO LIU and ZHENG-XI LI* \\ Department of Entomology and Key Laboratory of Pest Monitoring and Green Management, MOA, College of Plant \\ Protection, China Agricultural University, 2 Yuanmingyuan West Road, Beijing 100193, China; e-mails: zxli@cau.edu.cn, \\ 1696679923@qq.com
}

Key words. Homoptera, Aleyrodidae, Bemisia tabaci, reference gene, quantitative PCR, Wolbachia transfection

\begin{abstract}
Stable reference genes (RGs) determine the reliability of quantitative polymerase chain reaction (qPCR) analyses and it is recommended that different reference genes are used for different types of DNA and tissues. The present study aimed to screen for stable RGs for the qPCR analysis of the immune responses of the whitefly Bemisia tabaci to the Wolbachia wMel strain from Drosophila melanogaster. A total of eight candidate RGs were evaluated using five different methods, i.e., Coefficient of Variation analysis, GeNorm, NormFinder, BestKeeper and $\triangle \mathrm{Ct}$. The stability of these RGs was assessed for both genomic DNA (gDNA) and complementary DNA (cDNA). The results indicate that $\beta$-actin (Actin) and elongation factor 1 alpha (EF-1 $\alpha$ ) were the most stable RGs for gDNA, whereas $18 S$ rRNA (18S) and glyceraldehyde phosphate dehydrogenase (GAPDH) were the least stable; in contrast, Actin and GAPDH were the most stable for CDNA, whereas RPL29 and ATPase were the least stable. The effectiveness of the most stable RGs was then validated against the least stable using qPCR analysis of the titre of wMel (gDNA) and the transcriptional responses of the antimicrobial peptide Alo-3-like and the phosphatidylinositol-bisphosphate 3-kinase catalytic subunit delta isoform (cDNA) to wMel transfection. The results support the notion that reliable RGs are essential for a qPCR analysis of samples of both gDNA and cDNA.
\end{abstract}

\section{INTRODUCTION}

Real-time quantitative PCR (qPCR) is a commonly used technique for gene quantitation at both genomic DNA (gDNA) and complementary DNA (cDNA) levels, which recently has been used in many studies (Artico et al., 2010; Derveaux et al., 2010; Hindson et al., 2013). Nevertheless, the reliability of qPCR is affected by many different factors (Bustin, 2000; Derveaux et al., 2010) and the use of reference genes (RGs) can greatly improve the accuracy of qPCR results by standardizing or normalizing experimental data from different developmental stages, organs or tissues (Artico et al., 2010; Arya et al., 2017). Screening for stable RGs is reported for different species of insects, such as Aphis glycines (Bansal et al., 2012), Nilaparvata lugens (Yuan et al., 2014), Bactericera cockerelli (Ibanez \& Tamborindeguy, 2016) and Lipaphis erysimi (Koramutla et al., 2016). The RGs have to be carefully evaluated for particular situations, as it is unlikely that the same RGs (non-evaluated) are generally suitable (Thellin et al., 1999; Vandesompele et al., 2002; Ponton et al., 2011; Zhou \& $\mathrm{Li}, 2016)$. Several algorithms have been developed for evaluating the stability of RGs, including the Coefficient of Variation (Boda et al., 2009), GeNorm (Vandesompele et al., 2002), NormFinder (Andersen et al., 2004), BestKeeper (Pfaffl et al., 2004) and the $\Delta \mathrm{Ct}$ method (Silver et al., 2006). These algorithms have proved to be helpful in the screening for stable RGs in a variety of organisms (Freitag et al., 2018; Meng et al., 2019; Xie et al., 2019).

Whitefly Bemisia tabaci is a destructive agricultural pest and causes serious damage to vegetables, ornamental plants and other crops worldwide (De Barro et al., 2011; Navas-Castillo et al., 2011). B. tabaci is often infected with Wolbachia (Li et al., 2007), a group of maternally inherited intracellular Gram-negative bacteria frequently found in arthropods and filarial nematodes (Hilgenboecker et al., 2008; Zug \& Hammerstein, 2012). Wolbachia can manipulate host reproduction in different ways, block the transmission of human diseases and control insect pests (Bourtzis \& O'Neill, 1998; Stouthamer et al., 1999; Werren et al., 2008). However, the interactions between $\mathrm{Wol}$ bachia and their hosts are still poorly understood (Lemaitre $\&$ Hoffmann, 2007). In our research group, several exog-

\footnotetext{
* Corresponding author: e-mail: zxli@cau.edu.cn
} 
enous Wolbachia strains were successfully transferred into B. tabaci by microinjection and transinfected isofemale lines were established in the laboratory (Zhong \& Li, 2014; Hu \& Li, 2015; Zhou \& Li, 2016). Recently, we sequenced the transcriptomes of $B$. tabaci in response to Wolbachia transfection using the RNA-seq technique, which is necessary for a detailed investigation of the host-Wolbachia interaction, including qPCR analysis of the titre of Wolbachia and expression levels of differentially expressed genes (DEGs) and functional analysis of candidate genes via RNA interference (RNAi). All of these studies require the selection of suitable RGs. In a previous study, 15 candidate RGs were evaluated for $B$. tabaci using the algorithms geNorm and Normfinder (Li et al., 2013), which revealed that the stability of RGs was greatly affected by both biotic and abiotic factors, and that different RGs should be used depending on the species and conditions. The purpose of the present study was to screen for suitable RGs for qPCR analysis of both gDNA and cDNA from B. tabaci artificially transfected with exogenous Wolbachia. Based on our studies, different RGs are needed for determining the titre of Wolbachia or level of expression of functional genes in different generations when $B$. tabaci is transfected with the $w \mathrm{Mel}$ Wolbachia strain from the fruit fly Drosophila melanogaster.

\section{MATERIAL AND METHODS}

\section{Insect rearing and transfection through microinjection}

The whitefly B. tabaci (Q cryptic species) was collected in tomato greenhouses of Jinan Academy of Agricultural Sciences, Shandong, China, and then maintained on pot-grown plants of cotton in a laboratory $\left(14 \mathrm{~L}: 10 \mathrm{D}, \mathrm{RH} 60-80 \%, 27 \pm 1^{\circ} \mathrm{C}\right)$. The $4^{\text {th }}$-instar nymphs (pseudopupae) of $B$. tabaci were artificially transinfected with the $w \mathrm{Mel}$ Wolbachia strain by microinjection as described by Zhou \& Li (2016). The $w$ Mel strain was isolated from $D$. melanogaster using the Percoll density-gradient centrifugation method. The primer pair 81F/691R (Table 1) was used to verify the existence of the $w \mathrm{Mel}$ strain, and on each occasion a volume of $46 \mathrm{~nL}$ Wolbachia suspension was injected. After transfection, isofemale lines were established and samples were collected from subsequent generations $(\mathrm{G})$.

\section{Extraction of genomic DNA (gDNA) and synthesis of complementary DNA (cDNA)}

Twenty fresh whiteflies (adults) were used for extraction of gDNA from samples of $\mathrm{G}_{0}, \mathrm{G}_{2}, \mathrm{G}_{4}, \mathrm{G}_{6}$ and $\mathrm{G}_{7}$ individuals using the KAC method as described by Zhong \& Li (2013) and the purity and concentration of gDNA were checked using a NanoDrop ND-2000 (Thermo Scientific, Wilmington, DE). Samples of thirty fresh whiteflies were used for the extraction of total RNA in a 1.5-mL centrifuge tube containing TRIZol reagent (TransGen Biotech, Beijing, China), which were from $\mathrm{G}_{0}, \mathrm{G}_{1}$ and $\mathrm{G}_{4}$ of the transinfected isofemale lines, with the wild type as the control. The first-strand cDNA was synthesized from $500 \mathrm{ng}$ of total RNA using the PrimeScript ${ }^{\mathrm{TM}}$ RT reagent Kit (TaKaRa, Beijing, China) according to the supplier's instructions.

\section{Selection of RGs}

Eight RGs were selected: heat shock protein 20 (HSP20), heat shock protein 70 (HSP70), glyceraldehyde phosphate dehydrogenase (GAPDH), 60S ribosomal protein L29 (RPL29), $\beta$-actin (Actin), 18S rRNA (18S), elongation factor 1 alpha $(E F-1 a)$ and adenosine triphosphate enzyme (ATPase) (Table 1). Most of these genes have been used as internal references for real-time qPCR analysis in previous studies (Zhou et al., 1998; Li et al., 2013; Zhou \& Li, 2016). These RGs were evaluated against both gDNA and cDNA in the present study, but HSP20 and HSP70 were not used for cDNA samples as it is likely they are induced by Wolbachia transfection.

\section{Quantitative PCR analysis}

The specificity of the primers for the eight RGs (Table 1) was examined using PCR in a total reaction volume of $25 \mu \mathrm{L}$ containing $2 \mu \mathrm{L}$ DNA template, $1 \mu \mathrm{L}$ of each primer $(10 \mu \mathrm{M}), 2.5$ $\mu \mathrm{L} 10 \times$ PCR buffer (TransGen Biotech, Beijing, China), $2 \mu \mathrm{L}$ dNTPs $(2.5 \mathrm{mM}), 0.5 \mu \mathrm{L}$ Taq DNA polymerase $(5.0 \mathrm{U} / \mu \mathrm{L})$ and $16 \mu \mathrm{L} \mathrm{ddH_{2 }} \mathrm{O}$. The thermocycling program was: $94^{\circ} \mathrm{C}$ for $5 \mathrm{~min}$, 35 cycles of $94^{\circ} \mathrm{C}$ for $30 \mathrm{~s}, 60^{\circ} \mathrm{C}$ for $30 \mathrm{~s}, 72^{\circ} \mathrm{C}$ for $30 \mathrm{~s}$ and a final $10 \mathrm{~min}$ extension at $72^{\circ} \mathrm{C}$. PCR products were analysed using $1 \%$ agarose gel electrophoresis. For the qPCR analysis, the DNA templates (gDNA or cDNA) were successively diluted by $5^{0}, 5^{1}, 5^{2}, 5^{3}$ and $5^{4}$ times for construction of standard curves and melting curves. A suitable pair of primers for qPCR analysis should have a correlation coefficient $\left(R^{2}\right)>0.99$, an amplification efficiency $(E)>90 \%$ and a unimodal melting curve (Livak $\&$ Schmittgen, 2001). The reaction was performed in a total volume of $20 \mu \mathrm{L}$ containing $10 \mu \mathrm{L}$ AceQ $^{\circledR}$ SYBR $^{\circledR}$ Green Master Mix (Vazyme, Nanjing, China), $0.4 \mu \mathrm{L}$ of each primer $(10 \mu \mathrm{M}), 1$ $\mu \mathrm{L}$ DNA template and $8.2 \mu \mathrm{L} \mathrm{ddH}_{2} \mathrm{O}$ on ABI 7500 platform (Applied Biosystems, Foster City, California, USA); the primer pair $w s p Q 384 / w s p Q 513$ (Table 1) was used to detect the titre of $w \mathrm{Mel}$ strain in $B$. tabaci after transfection. The thermocycling program was $50^{\circ} \mathrm{C}$ for $2 \mathrm{~min}, 95^{\circ} \mathrm{C}$ for $5 \mathrm{~min}, 40$ cycles of $95^{\circ} \mathrm{C}$ for $10 \mathrm{~s}$ and $60^{\circ} \mathrm{C}$ for $30 \mathrm{~s}$. The program used for determining the melting curve was $95^{\circ} \mathrm{C}$ for $15 \mathrm{~s}, 60^{\circ} \mathrm{C}$ for $60 \mathrm{~s}$ and $95^{\circ} \mathrm{C}$ for $15 \mathrm{~s}$. DNase/ RNase-free water was used as the negative control. Each treatment was performed in triplicate.

\section{Stability of RGs}

The cycle threshold $(C t)$ values of RGs for different generations were compared in order to evaluate their stability. The working concentration of gDNA for the qPCR analysis was $20 \mathrm{ng} / \mu \mathrm{L}$ and that of cDNA was $100 \mathrm{ng} / \mu \mathrm{L}$. The stability of RGs was evaluated using four different algorithms: GeNorm (Vandesompele et al., 2002), NormFinder (Andersen et al., 2004), BestKeeper (Pfaffl et al., 2004) and $\Delta \mathrm{Ct}$ method (Silver et al., 2006). The four algorithms rated the stability according to different variables: GeNorm provides an $M$-value based on the average paired expression ratio. The lower the $M$-value, the more stable the expression: $M \leq 1.5$ was considered to be stable. NormFinder calculates stability based on the inter- and intra-group variance of each candidate RG; the lower the NormFinder value, the more stable the RG. BestKeeper determines the stability of RG according to the standard deviation (SD): The higher the SD, the more unstable the expression. $\Delta \mathrm{Ct}$ method performs pairwise multiple comparisons between the expression levels and identifies the most stable RGs. Each algorithm sorted RGs according to their stability and assigned the RGs a series of consecutive integers (starting at one) and the geometric average (geomean) of the weights based on the four algorithms was then calculated for each RG. The RG with the lowest geomean value was considered to be the most stable and the RGs were ranked accordingly. Subsequently, the Coefficient of Variation (CV) was used to measure the population variance of each gene as it is the only method that is not affected by other factors (Boda et al., 2009). Here a threshold of $\mathrm{CV}=50 \%$ was defined: genes with a $\mathrm{CV}$ value above this threshold were 
considered highly variable and excluded from further analyses. Finally, a corrected ranking of the RGs was obtained.

\section{Validation of RGs}

The reliability of candidate RGs was validated by a qPCR analysis of the titre of $w \mathrm{Mel}$ (gDNA) and the transcriptional response of two genes (antimicrobial peptide Alo-3-like; phosphatidylinositol-bisphosphate 3-kinase catalytic subunit delta isoform, $P l 3 K$ ) to $w \mathrm{Mel}$ transfection (cDNA) (the primer sequences are included in Table 1). Alo-3-like is an antimicrobial peptide involved in immune response of the host to $w \mathrm{Mel}$ transfection, and $P l 3 K$ is involved in the immune-related signalling pathway in $\mathrm{B}$. tabaci based on our transcriptome sequencing data (Tables $\mathrm{S} 1$ and $\mathrm{S} 2$; Figs S1 and S2). Here we used the two most stable and two least stable RGs based on their geomean values to normalize the qPCR analysis before the results were compared. The procedures for qPCR analysis were the same as described above.

\section{Data analysis}

The statistical differences were analysed using One-way ANOVA followed by Student Newman Keuls (SNK) test at 0.05 , 0.01 and 0.001 levels of probability on SPSS v.20.0 (SPSS Inc., Chicago, IL, USA).

\section{RESULTS}

\section{Specificity, amplification efficiency and cycle thresholds of RG primers}

The specificity of the RG primers (Table 1) was determined using PCR and agarose gel electrophoresis, which indicated that all primer pairs resulted in single specific bands of expected size. In addition, the melting curves of all the primer pairs had single peaks, and the correlation coefficients and amplification efficiencies of the standard curves were all within the range of $R^{2}>0.99$ and $90 \%<E$ $<110 \%$ (Table 1; Fig. S3). Moreover, the determination of
RG using qPCR revealed that the $C t$-value of $18 S$ was the lowest (the log of starting template copies) for both gDNA and cDNA templates, while that of $G A P D H$ was the highest for cDNA (Fig. 1) and that of RPL29 was the most variable (Fig. 1A).

\section{Stability of candidate RGs}

Based on qPCR analysis of gDNA and cDNA samples taken from transinfected $B$. tabaci adults and the different algorithms (GeNorm, NormFinder, BestKeeper or $\Delta \mathrm{Ct}$ method), stabilities were assigned to each RG and the geomeans of these stabilities calculated, which were used to determine their combined ranking (Table 2). The results indicated that ATPase and EF-1 $\alpha$ were the two most stable RGs for gDNA templates and RPL29 and GAPDH the two least stable RGs; in contrast, $18 S$ and Actin were the two most stable RGs for cDNA templates, whereas $E F-1 \alpha$ and ATPase were the two least stable RGs.

The CV analysis was the most appropriate method for identifying the most variable RGs, which were excluded from further assessments. The analysis showed that RPL29 and $E F-1 \alpha$ were the most variable RGs for both gDNA and cDNA samples (Table 3). After removing RPL29 and $E F-1 \alpha$ from the ranking analysis, a corrected stability ranking value was generated for each $R G$ using the different algorithms and finally all RGs were ranked according to their geomean values (Table 4). The results indicate that Actin and EF-1 $\alpha$ were the two most stable RGs for gDNA samples, whereas Actin and GAPDH were the two most stable for cDNA samples. Interestingly, $18 S / G A P D H$ and 18S/RPL29/ATPase were identified as the least stable RGs for both gDNA and cDNA samples.

Table 1. Primer sequences used in this study.

\begin{tabular}{|c|c|c|c|c|c|c|c|c|}
\hline \multirow{2}{*}{$\begin{array}{l}\text { Gene } \\
\text { name }\end{array}$} & \multirow{2}{*}{$\begin{array}{l}\text { GenBank } \\
\text { acc. no. }\end{array}$} & \multirow{2}{*}{ Primer sequence $\left(5^{\prime} \rightarrow 3^{\prime}\right)$} & \multirow{2}{*}{$\begin{array}{l}\text { Expected } \\
\text { size (bp) }\end{array}$} & \multicolumn{2}{|c|}{ gDNA } & \multicolumn{2}{|c|}{ cDNA } & \multirow{2}{*}{ References } \\
\hline & & & & $E \%$ & $R^{2}$ & $E \%$ & $R^{2}$ & \\
\hline HSP2O & EU934239 & $\begin{array}{l}\text { F: AAGAAGTCAGCGTGAAAGTCG } \\
\text { R: GTACCTCCTAGTGAAAGATCGG }\end{array}$ & 107 & 103.8 & 0.9986 & - & - & Li et al., 2013 \\
\hline HSP70 & EU934240 & $\begin{array}{c}\text { F: AGCACTCCGGCGTCTACG } \\
\text { R: CGAACCTGGCACGGGACAC }\end{array}$ & 134 & 108.4 & 0.9966 & - & - & Li et al., 2013 \\
\hline GAPDH & JU470454 & $\begin{array}{l}\text { F: GGACACGGAAAGCCATACCAG } \\
\text { R: ACCACCGCTACCCAAAAGACC }\end{array}$ & 166 & 102.7 & 0.9971 & 109 & 0.9965 & Li et al., 2013 \\
\hline RPL29 & EE596314 & $\begin{array}{c}\text { F: TCGGAAAATTACCGTGAG } \\
\text { R: GAACTTGTGATCTACTCCTCTCGTG }\end{array}$ & 144 & 107.4 & 0.9984 & 92.9 & 0.9939 & Li et al., 2013 \\
\hline Actin & AF071908 & $\begin{array}{l}\text { F: TCTTCCAGCCATCCTTCTTG } \\
\text { R: CGGTGATTTCCTTCTGCATT }\end{array}$ & 174 & 96.75 & 0.996 & 102.6 & 0.9999 & Zhou \& Li, 2016 \\
\hline $18 S$ & U20401 & $\begin{array}{l}\text { F: CGGCTACCACATCCAAGGAA } \\
\text { R: GCTGGAATTACCGCGGCT }\end{array}$ & 187 & 94.62 & 0.9941 & 104.9 & 0.9913 & Li et al., 2013 \\
\hline$E F-1 a$ & EE600682 & $\begin{array}{l}\text { F: ATGCCATGGTCAAGGGATGG } \\
\text { R: ACATCTGGAGTGGCAATCGG }\end{array}$ & 134 & 97.69 & 0.9951 & 110 & 0.9971 & $\begin{array}{c}\text { Designed } \\
\text { by the authors }\end{array}$ \\
\hline ATPase & JU470453 & $\begin{array}{l}\text { F: CGTTACTCCCCTCTTGGCTG } \\
\text { R: CAGAAGACGGCGATTCGAGA }\end{array}$ & 122 & 108.5 & 0.9943 & 107.7 & 0.996 & $\begin{array}{l}\text { Designed } \\
\text { by the authors }\end{array}$ \\
\hline$w s p$ & KU870673 & $\begin{array}{c}\text { 81F: TGGTCCAATAAGTGATGAAGAAAC } \\
\text { 691R: AAAAATTAAACGCTACTCCA }\end{array}$ & 632 & - & - & - & - & Zhou et al., 1998 \\
\hline $\begin{array}{l}\text { wspQ384 } \\
\text { wspQ513 }\end{array}$ & KU870673 & $\begin{array}{c}\text { F: TGGAACCCGCTGTGAATGAT } \\
\text { R: GCACCATAAGAACCGAAATAACG }\end{array}$ & 130 & 93.76 & 0.9976 & 95.46 & 0.9957 & Zhou \& Li, 2016 \\
\hline PI3K & LOC109034225 & $\begin{array}{l}\text { F: TGTTGCAACGTATGTGCTTGG } \\
\text { R: TAAGAATTGCCGCCTGGACT }\end{array}$ & 146 & 97.51 & 0.9987 & 93.14 & 0.9989 & $\begin{array}{l}\text { Designed } \\
\text { by the authors }\end{array}$ \\
\hline$A M P$ & LOC109033344 & $\begin{array}{l}\text { F: TTCCAAGCCAAAACCAACCAC } \\
\text { R: CCGTCTGAGAGGCAATTCGAT }\end{array}$ & 110 & 106.5 & 0.9961 & 108.2 & 0.9916 & $\begin{array}{l}\text { Designed } \\
\text { by the authors }\end{array}$ \\
\hline
\end{tabular}

${ }^{a} E \%$ - amplification efficiency; $R^{2}$ - correlation coefficient. 

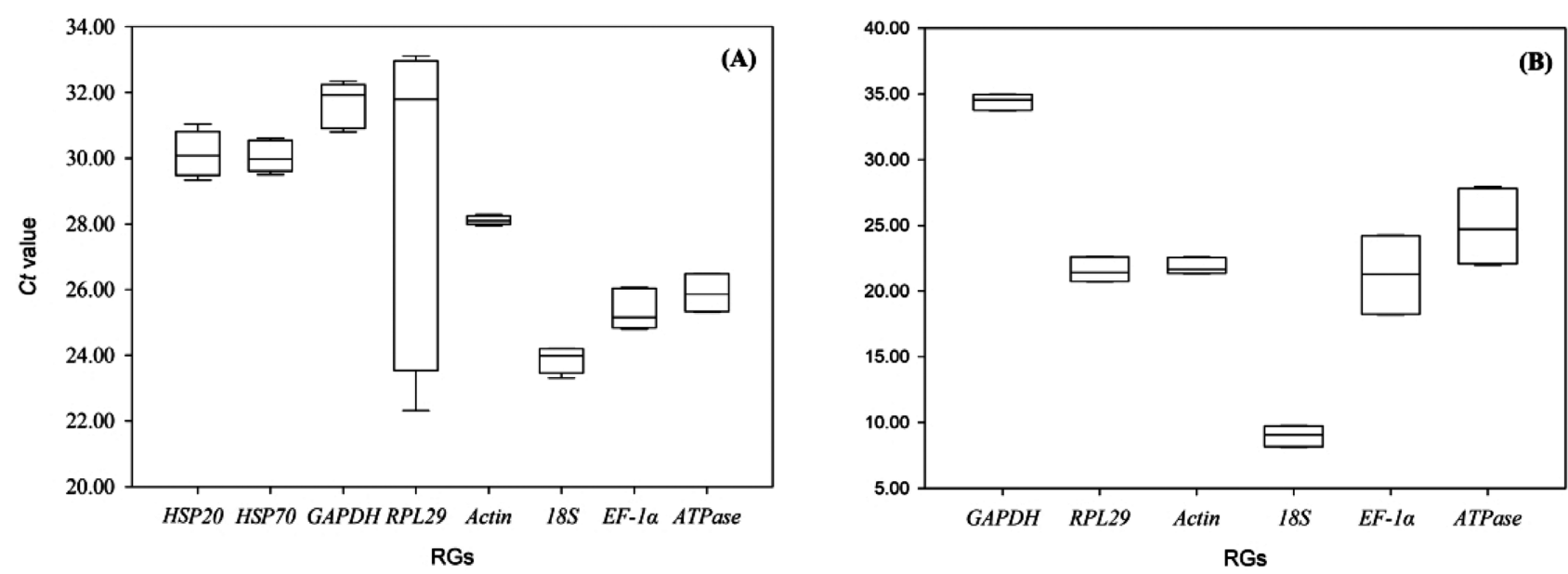

Fig. 1. A boxplot of the amplification efficiencies of the reference genes (RGs) based on the cycle threshold (Ct) of the qPCR analysis. The Ct values are those for gDNA (A) recorded in $G_{0}, G_{2}, G_{4}, G_{6}$ and $G_{7}$ of the transinfected isolines, and for cDNA (B) in $G_{0}, G_{1}$ and $G_{4}$ of the transinfected isolines and of the wild type. The line in the middle of the box represents the median value. The box indicates the $25 \%$ and $75 \%$ percentiles, and the extremities indicate the maximum and minimum values. The bigger the box, the greater the variation.

\section{Validation of stable RGs}

The qPCR analysis of the relative titre (gDNA) of the Wolbachia $w \mathrm{Mel}$ strain was normalized by using a combination of the two most stable (Actin and $E F-1 \alpha$ ) and two least stable ( $18 S$ and GAPDH) RGs. The results revealed that the measurement of Wolbachia titre was indeed affected by the nature of the RG in all of the five generations assessed in this study (Fig. 2). Specifically, the relative titres normalized by unstable RGs varied dramatically between generations, especially in $\mathrm{G}_{6}$ for which the titre was several-fold higher than in that recorded in other generations. In contrast, the titres normalized by stable RGs looked more normal.

The qPCR analysis of the relative expression (cDNA) of two immune-related genes ( $A M P$ and $P l 3 K$ ) was also normalized using a combination of the two most stable (Actin and $G A P D H)$ and two least stable (RPL29/ATPase) RGs. The results indicate that the relative level of expression of $A M P$ (Alo-3-like gene) when normalized by unstable RGs was very high in the wild type, while there were no significant differences between $\mathrm{G}_{0}$ and $\mathrm{G}_{4}$ and the control $\left(\mathrm{G}_{1}\right)$ (Fig. 3A). In the case of $P l 3 K$, the relative level of expression normalized by unstable RGs were exceptionally high in the wild type and in $\mathrm{G}_{0}$ of the transinfected lines (Fig. 3B). Moreover, the relative levels of expression of both the Alo-3-like gene and $P l 3 \mathrm{~K}$ when normalized using stable RGs were generally consistent with the transcriptome data, whereas those normalized using unstable RGs were not (Tables S1 and S2).

\section{DISCUSSION}

Our studies confirmed that the reference genes significantly affected the accuracy of qPCR analysis of both gDNA and cDNA samples. Moreover, the selection of candidate RGs based on the algorithms used in this study seemed very effective: the scoring and ranking procedures ensured the selection of suitable RGs for the qPCR analysis of both gDNA and cDNA templates. Our results support

Table 2. Rankings of selected internal reference genes based on different algorithms and a comprehensive calculation (geomean)

\begin{tabular}{|c|c|c|c|c|c|c|}
\hline Ref. gene & GeNorm $M$-value & NormFinder Stability & BestKeeper SD \pm CP & $\Delta \mathrm{Ct}$ method & Geomean & Ranking \\
\hline \multicolumn{7}{|c|}{ gDNA } \\
\hline ATPase & $0.253(1)$ & $0.0883(2)$ & $0.458(5)$ & $0.986(1)$ & 1.77 & 1 \\
\hline$E F-1 \alpha$ & $0.253(1)$ & $0.0882(1)$ & $0.503(6)$ & $0.988(2)$ & 1.86 & 2 \\
\hline HSP20 & $0.346(2)$ & $0.121(3)$ & $0.393(4)$ & $0.998(3)$ & 2.91 & 3 \\
\hline Actin & $0.528(4)$ & $0.475(5)$ & $0.074(1)$ & $1.05(5)$ & 3.16 & 4 \\
\hline HSP70 & $0.474(3)$ & $0.154(4)$ & $0.317(3)$ & $1.01(4)$ & 3.46 & 5 \\
\hline $18 S$ & $0.613(6)$ & $0.608(7)$ & $0.246(2)$ & $1.19(7)$ & 4.92 & 6 \\
\hline GAPDH & $0.578(5)$ & $0.555(6)$ & $0.504(7)$ & $1.14(6)$ & 5.95 & 7 \\
\hline RPL29 & $1.56(7)$ & $3.042(8)$ & $3.70(8)$ & $3.94(8)$ & 7.37 & 8 \\
\hline \multicolumn{7}{|c|}{ cDNA } \\
\hline$\overline{18 S}$ & $0.636(2)$ & $0.194(2)$ & $0.623(4)$ & $1.131(1)$ & 1.86 & 1 \\
\hline Actin & $0.296(1)$ & $0.621(4)$ & $0.493(2)$ & $1.29(3)$ & 2.21 & 2 \\
\hline GAPDH & $0.296(1)$ & $0.847(5)$ & $0.373(1)$ & $1.25(5)$ & 2.23 & 3 \\
\hline RPL29 & $0.841(3)$ & $0.194(1)$ & $0.604(3)$ & $1.01(2)$ & 2.37 & 4 \\
\hline ATPase & $1.49(4)$ & $0.528(3)$ & $0.805(5)$ & $1.21(4)$ & 3.94 & 5 \\
\hline$E F-1 \alpha$ & $1.70(5)$ & $1.78(6)$ & $2.55(6)$ & $2.29(6)$ & 5.73 & 6 \\
\hline
\end{tabular}

a The gDNA and cDNA samples are taken from transinfected $B$. tabaci adults. The final rankings are determined by geomean values calculated based on the algorithms GeNorm, NormFinder, BestKeeper and $\Delta \mathrm{Ct}$ method. The numbers in brackets indicate the ranking values based on individual algorithms. 
Table 3. Stability of internal reference genes based on a Coefficient of Variation (CV) analysis.

\begin{tabular}{lcc}
\hline Ref. gene & CV\% & Ranking \\
\hline Actin & gDNA & 1 \\
HSP70 & 11.71 & 2 \\
18S & 26.26 & 3 \\
EF-1a & 28.99 & 4 \\
ATPase & 33.5 & 5 \\
HSP20 & 33.56 & 6 \\
GAPDH & 35.4 & 7 \\
RPL29 & 39.89 & 8 \\
\hline & 191.27 & \\
\hline Actin & cDNA & 1 \\
GAPDH & 28.27 & 2 \\
RPL29 & 34.17 & 3 \\
ATPase & 43.62 & 4 \\
18S & 43.77 & 5 \\
EF-1a & 43.91 & 6 \\
\hline
\end{tabular}

the notion that the use of suitable RGs is essential for a qPCR analysis.

The $w$ Mel Wolbachia strain from D. melanogaster is able to establish and induce strong cytoplasmic incompatibility (CI) in B. tabaci (Zhou \& Li, 2016), an important worldwide agricultural pest, which indicates it might be possible to use it to control this pest. Nevertheless, the titre of $w \mathrm{Mel}$ fluctuated during transgenerational transmission in $B$. tabaci. For instance, the titre of $w \mathrm{Mel}$ was extremely low after transfection in $G_{1-2}$ and $G_{2}$ and higher in $G_{4-6}$. This observation prompted us to speculate that the titre of Wolbachia might be modulated by the interaction between the host and Wolbachia. Obviously, clarifying the quantitative relationships between the titre of Wolbachia and the levels of expression of the candidate genes involved in the host-Wolbachia interaction would help us understand the mechanisms underlying the fluctuations in the Wolbachia titre, especially when the titre is potentially related to the pest control capability of Wolbachia (Breeuwer \& Werren, 1993; Noda et al., 2001). Therefore, it is essential to quantitatively measure both the titre of Wolbachia (gDNA) and the levels of expression (cDNA) of functional genes, and thus the screening for stable RGs for both gDNA and
cDNA samples is a prerequisite for a reliable qPCR analysis. In the present study, a combination of algorithms was used to evaluate the candidate RGs, which circumvented the drawbacks of using a single algorithm, and the results indicate that use of the stable RGs rather than unstable RGs could result in more reliable qPCR data. Indeed, the stable RGs specifically identified in this study were successfully used in the qPCR analysis of both gDNA and cDNA samples from B. tabaci artificially transfected with Wolbachia, which will facilitate the study of the host insect-Wolbachia interaction.

Different algorithms were developed for selecting RGs in the past, but as mentioned above, each algorithm has advantages and disadvantages, which potentially generate biased results. The use of a combination of algorithms may hopefully counteract any bias. For instance, GeNorm and BestKeeper are based on paired comparisons, and the selection of the most appropriate RGs are based on the change in the expression of genes, which does not eliminate the influence of co-regulation; on the other hand, Nor$\mathrm{mFinder}$ and the $\Delta \mathrm{Ct}$ method can neutralize this influence. Here we used geomeans to aggregate the RGs and generated an integrated ranking for the candidate RGs and the most variable RGs based on the CV analysis were not used in this study. Our corrected results indicate that the combined analysis worked well in selecting stable RGs.

The overall design of our experiments was based on the results of our previous study of the wMel Wolbachia strain after transfection by microinjection, which revealed the titre of $w \mathrm{Mel}$ differed greatly in the different generations. As noted above, the change in titre was most marked from $\mathrm{G}_{0}$ to $\mathrm{G}_{6}$; hence, the samples (both gDNA and cDNA) were collected during this period of time. Hopefully, the change in the expression of the functional genes selected and the titre of Wolbachia were effectively detected. In addition, the selection of immune-related genes for validating the RGs was based on those genes that were identified by the transcriptome sequencing, which revealed that an active immune response was induced after infection with Wolbachia, and thus they will be functionally analysed in the next step. The antimicrobial peptide Alo-3 was greatly

Table 4. Corrected rankings of reference genes.

\begin{tabular}{|c|c|c|c|c|c|c|}
\hline Ref. gene ${ }^{a}$ & GeNorm $M$-value & NormFinder Stability & BestKeeper SD $\pm \mathrm{CP}$ & $\Delta$ Ct method & Geomean & Ranking \\
\hline \multicolumn{7}{|c|}{ gDNA } \\
\hline Actin & $0.528(4)$ & $0.231(1)$ & $0.138(1)$ & $0.536(4)$ & 2 & 1 \\
\hline$E F-1 \alpha$ & $0.253(1)$ & $0.271(3)$ & $0.503(6)$ & $0.518(1)$ & 2.06 & 2 \\
\hline$H S P 2 O$ & $0.346(2)$ & $0.268(2)$ & $0.394(4)$ & $0.534(3)$ & 2.63 & 3 \\
\hline ATPase & $0.253(1)$ & $0.279(5)$ & $0.458(5)$ & $0.532(2)$ & 2.66 & 4 \\
\hline HSP7O & $0.474(3)$ & $0.276(4)$ & $0.317(3)$ & $0.549(5)$ & 3.66 & 5 \\
\hline $18 S$ & $0.631(6)$ & $0.462(7)$ & $0.298(2)$ & $0.685(7)$ & 4.92 & 6 \\
\hline GAPDH & $0.578(5)$ & $0.402(6)$ & $0.504(7)$ & $0.637(6)$ & 5.95 & 7 \\
\hline \multicolumn{7}{|c|}{ cDNA } \\
\hline$\overline{\text { Actin }}$ & $0.297(1)$ & $0.444(3)$ & $0.394(2)$ & $0.721(2)$ & 1.86 & 1 \\
\hline GAPDH & $0.297(1)$ & $0.614(4)$ & $0.373(1)$ & $0.923(4)$ & 2 & 2 \\
\hline $18 S$ & $0.636(2)$ & $0.158(1)$ & $0.704(4)$ & $0.812(3)$ & 2.21 & 3 \\
\hline RPL29 & $0.774(3)$ & $0.358(2)$ & $0.604(3)$ & $0.716(1)$ & 2.21 & 3 \\
\hline ATPase & $0.841(4)$ & $0.738(5)$ & $0.805(5)$ & $0.973(5)$ & 4.4 & 4 \\
\hline
\end{tabular}

${ }^{a} R P L 29$ and $E F-1 \alpha$ are excluded from gDNA and cDNA samples, respectively, in the corrected ranking analysis based on their highest CV values (Table 3 ). 


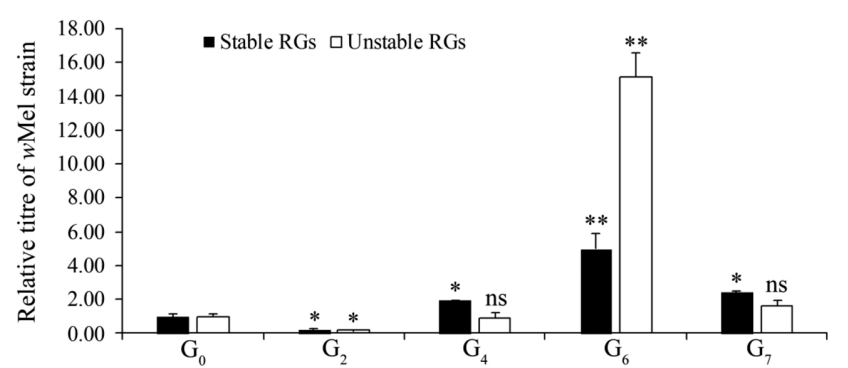

Fig. 2. Validation of stable RGs based on the qPCR analysis of the relative titre (gDNA) of $w$ Mel normalized by a combination of the two most stable RGs (Actin and EF-1 $\alpha$ ) and two least stable RGs (18S and GAPDH). The data are the means \pm standard deviation of the three replicates. $G_{0}$ is used as the control in the statistical analysis using One-way ANOVA followed by SNK test at 0.05 0.01 and 0.001 levels of probability (ns - not significant; ${ }^{*} P<0.05$; $\left.{ }^{* *} P<0.01 ;{ }^{* * *} P<0.001\right) . G_{0}$ - adults that were microinjected with the wMel strain; $G_{2}-2^{\text {nd }}$ generation after transfection; $G_{4}-4^{\text {th }}$ generation after transfection; $\mathrm{G}_{6}-6^{\text {th }}$ generation after transfection; $\mathrm{G}_{7}$ $-7^{\text {th }}$ generation after transfection.

down-regulated, while the $P L 3 K$ involved in the immunerelated signalling pathway was significantly up-regulated (Tables S1 and 2), indicating that these immune genes might play a role in the modulation of the titre of $w \mathrm{Mel}$ and in the immune reaction of the host to the Wolbachia. The results obtained in the present study confirmed the reliability of the transcriptome sequencing.

The RGs selected here are extensively used in other studies. Taking Actin as an example, it encodes a major component of the protein scaffold that supports the cell and determines its shape. Actin is well expressed in most types of cells and is widely used as an RG in the qPCR analysis of many different insects, including whitefly (Zhou \& Li, 2016), desert locust (Van Hiel et al., 2009), European honey bee (Scharlaken et al., 2008) and two species of Collembola (Van Hiel et al., 2009). Our results indicate that Actin and $E F-1 \alpha$ are the most stable RGs for gDNA samples of B. tabaci, while Actin and $G A P D H$ were the top two RGs for cDNA samples. Similarly, $E F-1 \alpha$ is used as an RG for salmon (Olsvik et al., 2005), humans (Shen et al., 2010; Silver et al., 2006), Orthoptera (Van et al., 2009) and Hymenoptera (Horňáková et al., 2010). Nevertheless, $G A P D H$, the commonly used RG in many species is reported to be unstable in some studies (Tong et al., 2009; Martins et al., 2016). It is also noteworthy that RPL29 is a recommended reference gene for several conditions, including different host plants, TYLCV infection, different developmental stages and tissues (Li et al., 2013). However, it is not recommended for use in studies on the artificial transfection of exogenous Wolbachia into B. tabaci, which further supports the notion that different reference genes should be used in different systems.

\section{CONCLUSIONS}

We developed a set of suitable RGs for studying the host insect-Wolbachia interaction using the agricultural pest B. tabaci artificially transfected with an exogenous strain of Wolbachia. The RGs are suitable for both gDNA and cDNA templates. A more reliable qPCR analysis of the
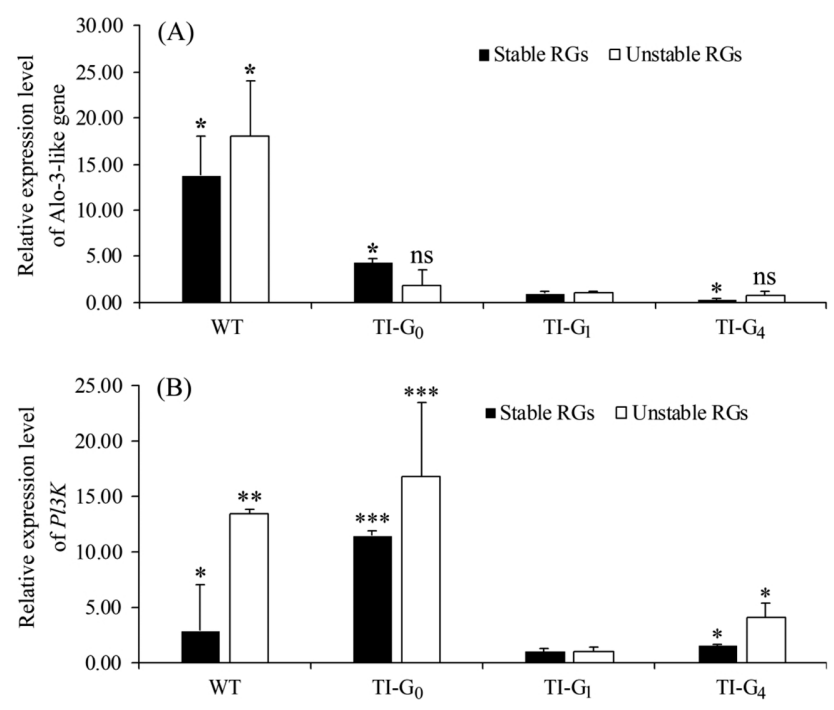

Fig. 3. Validation of stable RGs by $\mathrm{qPCR}$ analysis of the relative expression levels of $A M P I P I 3 K$ normalized by the combination of the two most stable RGs (Actin and GAPDH) and two least stable RGs (RPL29 and ATPase). (A) AMP, antimicrobial peptide Alo-3like; (B) $P I 3 K$, phosphatidylinositol-bisphosphate 3-kinase catalytic subunit delta isoform. The data are means \pm standard deviations of three replicates. TI-G is used as the control in the statistical analysis using One-way ANOVA followed by SNK test at $0.05,0.01$ and 0.001 levels of probability (ns - not significant; ${ }^{*} P<0.05$; ${ }^{* *} P<0.01$; ${ }^{* \star \star} P<0.001$ ). WT - wild-type; $\mathrm{TI}$ - transfected isoline; $\mathrm{G}_{0}$ - adults emerged after microinjection with the wMel strain; $G_{1}-1^{\text {st }}$ generation; $\mathrm{G}_{4}-4^{\text {th }}$ generation.

titre of Wolbachia and the expression of functional genes will increase our understanding of the infection dynamics of Wolbachia in this pest insect, which might provide a scientific basis for the development of a CI-based control strategy for this pest.

ACKNOWLEDGEMENTS. This work is supported by the National Natural Science Foundation of China (Grant nos. 31772169 and 31972267).

\section{REFERENCES}

Andersen C.L., Jensen J.L. \& ØRNToft T.F. 2004: Normalization of real-time quantitative reverse transcription-PCR data: a model-based variance estimation approach to identify genes suited for normalization, applied to bladder and colon cancer data sets. - Cancer Res. 64: 5245-5250.

Artico S., Nardeli S.M., Brilhante O., Grossi-de-Sa M.F. \& Alves-Ferreira M. 2010: Identification and evaluation of new reference genes in Gossypium hirsutum for accurate normalization of real-time quantitative RT-PCR data. - BMC Plant Biol. 10: 49, 12 pp.

Arya S.K., Jain G., Upadhyay S.K., Singh H., Dixit S. \& Verma P.C. 2017: Reference genes validation in Phenacoccus solenopsis under various biotic and abiotic stress conditions. Sci. Rep. 7: 13520, 12 pp.

Bansal R., Mamidala P., Mian M.R., Mittapalli O. \& Michel A.P. 2012: Validation of reference genes for gene expression studies in Aphis glycines (Hemiptera: Aphididae). - J. Econ. Entomol. 105: 1432-1438.

Boda E., Pini A., Hoxha E., Parolisi R. \& Tempia F. 2009: Selection of reference genes for quantitative real-time RT-PCR studies in mouse brain. - J. Mol. Neurosci. 37: 238-253. 
Bourtzis K. \& O’Neill S. 1998: “Wolbachia” Infections and arthropod reproduction. - Bioscience 48: 287-293.

Breeuwer J.A. \& Werren J.H. 1993: Cytoplasmic incompatibility and bacterial density in Nasonia vitripennis. - Genetics 135: $565-574$.

Bustin S.A. 2000: Absolute quantification of mRNA using realtime reverse transcription polymerase chain reaction assays. J. Mol. Endocrinol. 25: 169-193.

De Barro P.J., Liu S.S., Boykin L.M. \& Dinsdale A.B. 2011: Bemisia tabaci: a statement of species status. - Annu. Rev. Entomol. 56: 1-19.

Derveaux S., Vandesompele J. \& Hellemans J. 2010: How to do successful gene expression analysis using real-time PCR. Methods 50: 227-230.

Freitag D., Koch A., McLean A.L., Kalff R. \& Walter J. 2018: Validation of reference genes for expression studies in human meningiomas under different experimental settings. - Mol. Neurobiol. 55: 5787-5797.

Hilgenboecker K., Hammerstein P., Schlattmann P., Telschow A. \& WerRen J.H. 2008: How many species are infected with Wolbachia? A statistical analysis of current data. - FEMS Microbiol. Lett. 281: 215-220.

Hindson C.M., Chevillet J.R., Briggs H.A., Gallichotte E.N., RuF I.K., Hindson B.J. \& TEWARI M. 2013: Absolute quantification by droplet digital PCR versus analog real-time PCR. - Nat. Methods 10: 1003.

Horñáková D., MatoušKová P., Kindl J., Valterová I. \& PichoVÁ I. 2010: Selection of reference genes for real-time polymerase chain reaction analysis in tissues from Bombus terrestris and Bombus lucorum of different ages. - Anal. Biochem. 397: $118-120$

Hu H.Y. \& Li Z.X. 2015: A novel Wolbachia strain from the rice moth Corcyra cephalonica induces reproductive incompatibility in the whitefly Bemisia tabaci: sequence typing combined with phenotypic evidence. - Environ. Microbiol. Rep. 7: $508-515$.

IBANEZ F. \& TAMBoRINDEGUY C. 2016: Selection of reference genes for expression analysis in the potato psyllid, Bactericera cockerelli. - Insect Mol. Biol. 25: 227-238.

Koramutla M.K., Aminedi R. \& Bhattacharya R. 2016: Comprehensive evaluation of candidate reference genes for qRTPCR studies of gene expression in mustard aphid, Lipaphis erysimi (Kalt). - Sci. Rep. 6: 25883, 10 pp.

Lemaitre B. \& Hoffmann J. 2007: The host defense of Drosophila melanogaster. - Annu. Rev. Immunol. 25: 697-743.

Li Z.X., Lin H.Z. \& Guo X.P. 2007: Prevalence of Wolbachia infection in Bemisia tabaci. - Curr. Microbiol. 54: 467-471.

Li R., XIE W., Wang S., Wu Q., Yang N., Yang X. \& Zhou X. 2013: Reference gene selection for qRT-PCR analysis in the sweetpotato whitefly, Bemisia tabaci (Hemiptera: Aleyrodidae). - PLoS ONE 8: e53006, 8 pp.

Livak K.J. \& Schmittgen T.D. 2001: Analysis of relative gene expression data using real-time quantitative PCR and the $2^{-\triangle \Delta C T}$ method. - Methods 25: 402-408.

Martins P.K., Mafra V., De Souza W.R., Ribeiro A.P., Vinecky F., Basso M.F. \& Molinari H.B.C. 2016: Selection of reliable reference genes for RT-qPCR analysis during developmental stages and abiotic stress in Setaria viridis. - Sci. Rep. 6: 28348, $10 \mathrm{pp}$.

Meng H., Yang Y., Gao Z.H. \& Wei J.H. 2019: Selection and validation of reference genes for gene expression studies by RT-PCR in Dalbergia odorifera. - Sci. Rep. 9: 3341, 10 pp.

Navas-Castillo J., Fiallo-Olivé E. \& Sánchez-Campos S. 2011: Emerging virus diseases transmitted by whiteflies. - Ann. Rev. Phytopathol. 49: 219-248.
Noda H., Kolzumi Y., Zhang Q. \& Deng K. 2001: Infection density of Wolbachia and incompatibility level in two planthopper species, Laodelphax striatellus and Sogatella furcifera. - Insect Biochem. Mol. Biol. 31: 727-737.

Olsvik P.A., Lie K.K., Jordal A.E.O., Nilsen T.O. \& Hordvik I. 2005: Evaluation of potential reference genes in real-time RTPCR studies of Atlantic salmon. - BMC Mol. Biol. 6: 21, 9 pp.

Pfaffl M.W., Tichopad A., Prgomet C. \& Neuvians T.P. 2004: Determination of stable housekeeping genes, differentially regulated target genes and sample integrity: BestKeeper-Excelbased tool using pair-wise correlations. - Biotechnol. Lett. 26: 509-515.

Ponton F., Chapuis M.P., Pernice M., Sword G.A. \& Simpson S.J. 2011: Evaluation of potential reference genes for reverse transcription-qPCR studies of physiological responses in Drosophila melanogaster. - J. Insect Physiol. 57: 840-850.

Scharlaken B., de Graaf D.C., Goossens K., Brunain M., PeelMAN L.J. \& JACOBS F.J. 2008: Reference gene selection for insect expression studies using quantitative real-time PCR: The head of the honeybee, Apis mellifera, after a bacterial challenge. - J. Insect Sci. 8: 33, $10 \mathrm{pp}$.

Shen Y., Li Y., Ye F., Wang F., Lu W. \& XIE X. 2010: Identification of suitable reference genes for measurement of gene expression in human cervical tissues. - Anal. Biochem. 405: 224-229.

Silver N., Best S., Jiang J. \& Thein S.L. 2006: Selection of housekeeping genes for gene expression studies in human reticulocytes using real-time PCR. - BMC Mol. Biol. 7: 33, 9 pp.

Stouthamer R., Breeuwer J.A. \& Hurst G.D. 1999: Wolbachia pipientis: microbial manipulator of arthropod reproduction. Annu. Rev. Microbiol. 53: 71-102.

Thellin O., Zorzi W., Lakaye B., De Borman B., Coumans B., Hennen G. \& Heinen E. 1999: Housekeeping genes as internal standards: use and limits. - J. Biotechnol. 75: 291-295.

Tong Z., Gao Z., Wang F., Zhou J. \& Zhang Z. 2009: Selection of reliable reference genes for gene expression studies in peach using real-time PCR. - BMC Mol. Biol. 10: 71, 13 pp.

Vandesompele J., De Preter K., Pattyn F., Poppe B., Van Roy N., De Paepe A. \& Speleman F. 2002: Accurate normalization of real-time quantitative RT-PCR data by geometric averaging of multiple internal control genes. - Genome Biol. 3: research0034-1, 12 pp.

Van Hiel M.B., Van Wielendaele P., Temmerman L., Van Soest S., Vuerinckx K., Huybrechts R. \& Simonet G. 2009: Identification and validation of housekeeping genes in brains of the desert locust Schistocerca gregaria under different developmental conditions. - BMC Mol. Biol. 10: 56, 10 pp.

WerRen J.H., BALdo L. \& Clark M.E. 2008: Wolbachia: master manipulators of invertebrate biology. - Nat. Rev. Microbiol. 6: $741-751$.

Xie L.H., Quan X., Zhang J., Yang Y.Y., Sun R.H., Xia M.C. \& YANG L.R. 2019: Selection of reference genes for real-time quantitative PCR normalization in the process of Gaeumannomyces graminis var. tritici infecting wheat. - Plant Pathol. J. 35: 11-18.

Yuan M., Lu Y., Zhu X., Wan H., Shakeel M., Zhan S. \& Li J. 2014: Selection and evaluation of potential reference genes for gene expression analysis in the brown planthopper, Nilaparvata lugens (Hemiptera: Delphacidae) using reverse-transcription quantitative PCR. - PLoS ONE 9: e86503, 10 pp.

ZHONG Y. \& Li Z.X. 2013: Influences of tetracycline on the reproduction of the B biotype of Bemisia tabaci (Homoptera: Aleyrodidae). - Appl. Entomol. Zool. 48: 241-246. 
ZHONG Y. \& Li Z.X. 2014: Bidirectional cytoplasmic incompatibility induced by cross-order transfection of Wolbachia: Implications for control of the host population. - Microb. Ecol. 68: 463-471.

Zноu X.F. \& Li Z.X. 2016: Establishment of the cytoplasmic incompatibility-inducing Wolbachia strain $w \mathrm{Mel}$ in an important agricultural pest insect. - Sci. Rep. 6: 39200, 9 pp.
Zhou W., Rousset F. \& O’Neill S. 1998: Phylogeny and PCRbased classification of Wolbachia strains using wsp gene sequences. - Proc. Biol. Sci. 265: 509-515.

Zug R. \& Hammerstein P. 2012: Still a host of hosts for Wolbachia: analysis of recent data suggests that $40 \%$ of terrestrial arthropod species are infected. - PLOS ONE 7: e38544, 3 pp.

Received August 28, 2019; revised and accepted November 4, 2019

Published online November 15, 2019

Table S1. DEGs involved in the immune-related signalling pathways.

\begin{tabular}{|c|c|c|c|}
\hline Pathway / Gene ID & Annotated function & GenBank acc. no. & $\overline{\log _{2}(\mathrm{FC})^{\mathrm{a}}}$ \\
\hline \multicolumn{4}{|l|}{ Recognition } \\
\hline gene5108 & Peptidoglycan recognition protein 2-like (PGRP) & LOC109032651 & -1.96 \\
\hline \multicolumn{4}{|c|}{ 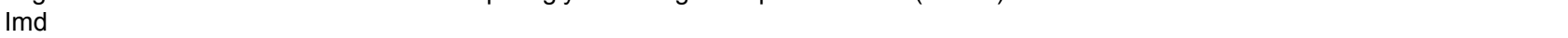 } \\
\hline gene1970 & RING-box protein $1 \mathrm{~A}$ & LOC109044484 & -1.22 \\
\hline gene7989 & RING-box protein 2 & LOC109035809 & -1.96 \\
\hline gene1881 & RING finger protein 207-like & LOC109044343 & 2.00 \\
\hline gene15250 & Mitogen-activated protein kinase kinase kinase (MAP3K) & LOC109043842 & -1.03 \\
\hline gene13482 & Mitogen-activated protein kinase kinase kinase (MAP3K) & LOC109041956 & 2.26 \\
\hline \multicolumn{4}{|c|}{ 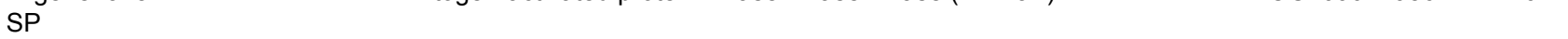 } \\
\hline gene3222 & Putative serine protease $\mathrm{K} 12 \mathrm{H} 4.7$ & LOC109030575 & -2.15 \\
\hline gene8224 & Putative serine protease F56F10.1 & LOC109036101 & -2.15 \\
\hline gene9459 & Venom serine protease Bi-VSP-like & LOC109037519 & -1.71 \\
\hline gene6008 & Transmembrane protease, serine 9 & LOC109033755 & -2.13 \\
\hline gene10506 & Serine protease nudel & LOC109038630 & 3.83 \\
\hline gene3265 & Serpin B3-like & LOC109030665 & -3.16 \\
\hline \multicolumn{4}{|l|}{ Toll } \\
\hline gene1030 & Protein spätzle-like & LOC109040362 & -3.84 \\
\hline gene6128 & Toll-like receptor 7 & LOC109033743 & -1.47 \\
\hline gene13805 & Toll-like receptor & LOC109042320 & 1.03 \\
\hline \multicolumn{4}{|c|}{ PI3K/AMPK/mTOR } \\
\hline gene6501 & Phosphatidylinositol-bisphosphate 3-kinase catalytic subunit delta isoform (PI3K) & LOC109034225 & 2.83 \\
\hline gene12334 & 5'-AMP-activated protein kinase subunit gamma-2 (AMPK) & LOC109040764 & 1.09 \\
\hline gene14490 & DNA-dependent protein kinase catalytic subunit (mTOR) & LOC109043096 & 1.19 \\
\hline gene9417 & Ribosomal protein S6 kinase beta-1 & LOC109037417 & 1.42 \\
\hline
\end{tabular}

a Only the genes with $q$ value $<0.005$ and $\left|\log _{2}(F C)\right|>1$ (significantly regulated) are listed. FC - fold change. The same below. ${ }^{b}$ The gene in bold was used in the validation of the RGs.

Table S2. DEGs involved in the immune responses of the host.

\begin{tabular}{|c|c|c|c|}
\hline Category/Gene ID & Annotated function & GenBank acc. no. & $\log _{2}(\mathrm{FC})$ \\
\hline \multicolumn{4}{|l|}{ AMP } \\
\hline gene553 & Antimicrobial peptide Alo-3-like ${ }^{a}$ & LOC109033344 & -3.02 \\
\hline \multicolumn{4}{|l|}{ Lysozyme } \\
\hline gene12425 & Lysozyme-like & LOC109040865 & 2.11 \\
\hline gene13644 & Lysozyme C, milk isozyme-like & LOC109042207 & -6.47 \\
\hline \multicolumn{4}{|l|}{ Phagocytosis } \\
\hline gene3382 & Down syndrome cell adhesion molecule-like protein Dscam2 & LOC109030752 & 1.38 \\
\hline gene8209 & Down syndrome cell adhesion molecule-like protein Dscam2 & LOC109036103 & 1.11 \\
\hline gene9357 & cdc42 homolog & LOC109037334 & 1.28 \\
\hline gene14561 & cdc42 homolog & LOC109043068 & 1.17 \\
\hline gene6552 & Partitioning defective 3 homolog & LOC109034237 & 1.38 \\
\hline gene3743 & Epidermal growth factor receptor (Efgr) & LOC109031082 & 1.44 \\
\hline gene2039 & Epidermal growth factor receptor substrate 15 -like & LOC109044512 & 1.33 \\
\hline gene11461 & Dynamin & LOC109039701 & 1.70 \\
\hline gene6591 & Myc box-dependent-interacting protein 1 & LOC109034291 & 1.65 \\
\hline gene9406 & G protein-coupled receptor kinase 1 & LOC109037372 & 1.26 \\
\hline gene9298 & Protein disabled (Dab1) & LOC109037388 & 1.43 \\
\hline gene15013 & Tyrosine-protein kinase Src64B & LOC109043668 & 1.19 \\
\hline gene1358 & Ras-like GTP-binding protein Rho1 & LOC109040974 & 1.02 \\
\hline gene 9020 & Ras-related protein Rad-11A & LOC109037003 & 1.04 \\
\hline gene9786 & EH domain-containing protein & LOC109037843 & 1.20 \\
\hline gene12339 & EH domain-containing protein 1-like & LOC109040805 & 1.26 \\
\hline gene4313 & Rab11 family-interacting protein & LOC109031749 & 1.06 \\
\hline \multicolumn{4}{|l|}{ Encapsulation } \\
\hline gene7278 & Integrin alpha-PS2-like & LOC109035063 & 1.24 \\
\hline gene4193 & Integrin beta-PS & LOC109031639 & 1.47 \\
\hline gene7161 & Rho GTPase-activating protein gacZ-like & LOC109034894 & 1.95 \\
\hline gene7940 & Rho GTPase-activating protein 10-like & LOC109035840 & 1.16 \\
\hline
\end{tabular}

a The gene in bold was used in the validation of the RGs. 
(A)

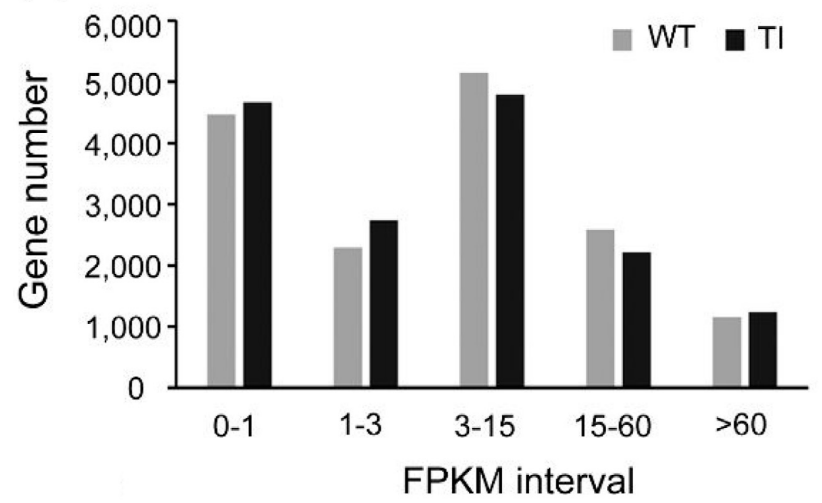

(B) TI/WT

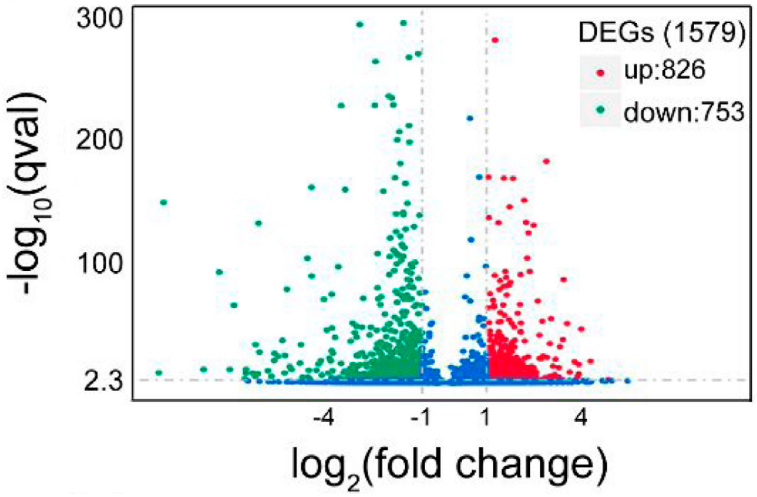

Fig. S1. Distribution of UniGenes per FPKM interval (A) and Volcanoplot of DEGs (B). The up- and down-regulated genes are indicated by red and green dots, respectively. Blue dots indicate no significant difference.

(A)

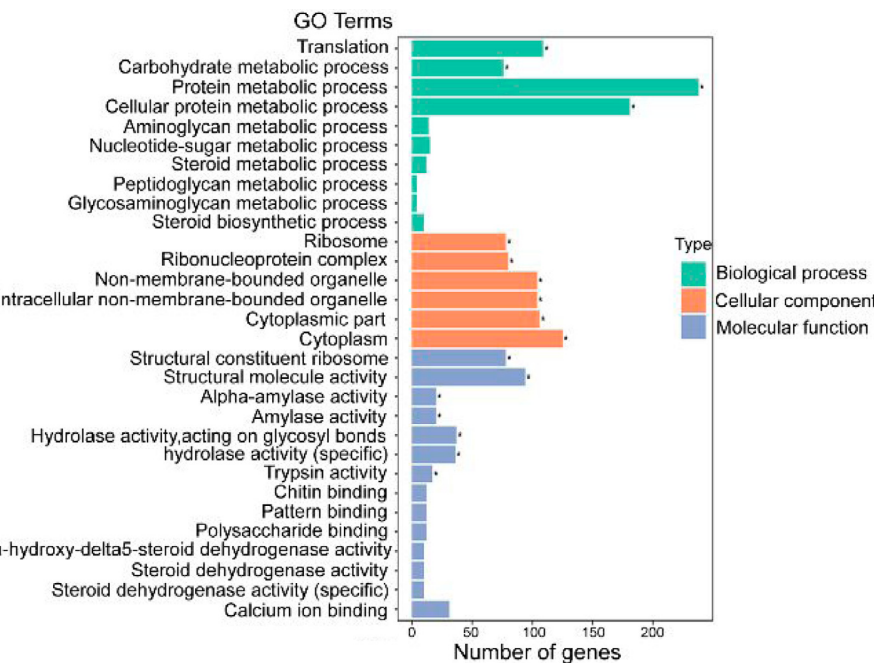

(B)

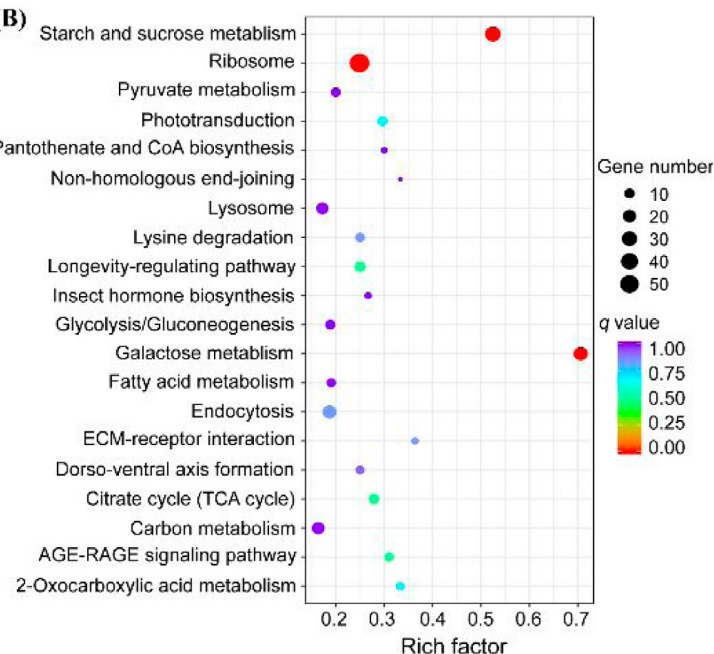

Fig. S2. GO (A) and KEGG (B) pathway enrichment analyses of DEGs. $q$ value: the corrected $P$ value, indicating a significant difference between WT and TI. Rich factor: The ratio of DEG numbers annotated in a given pathway to all the genes annotated in that pathway. 
(A)
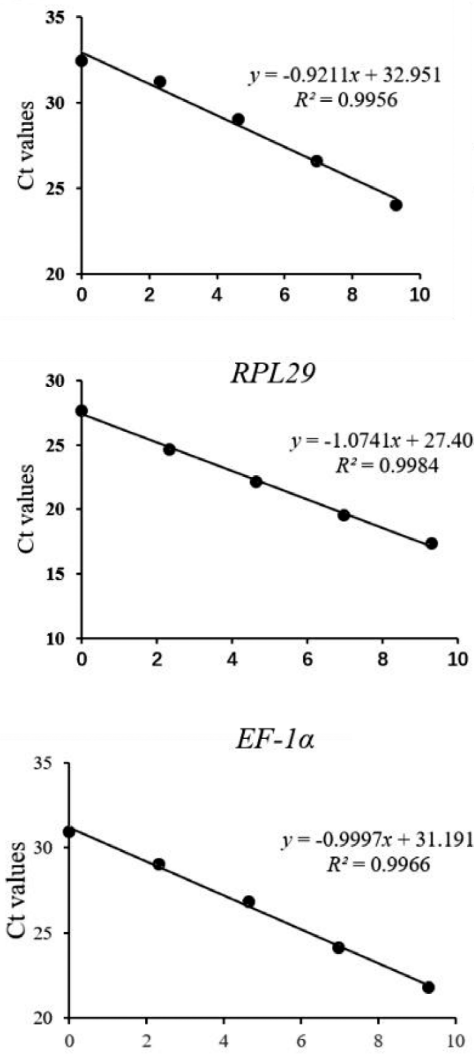

HSP70
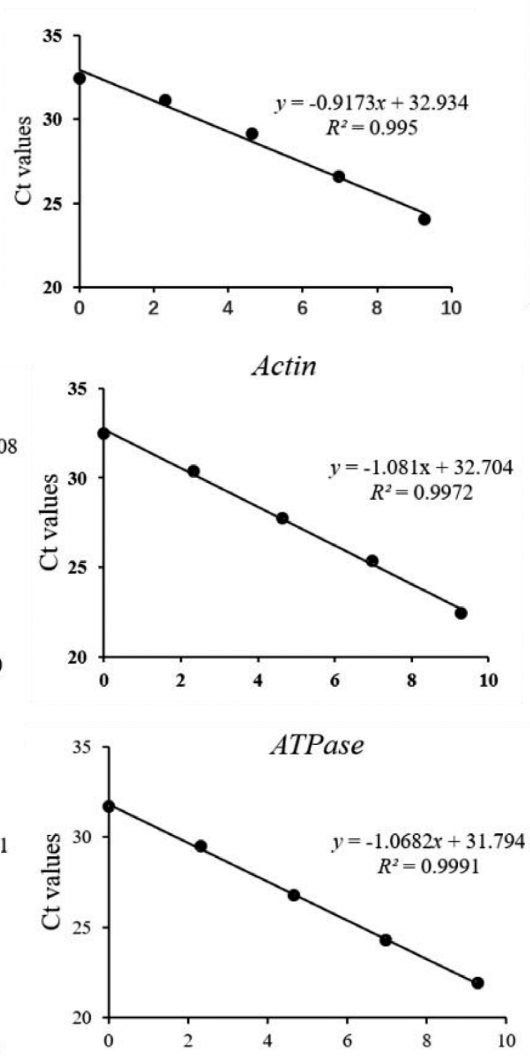
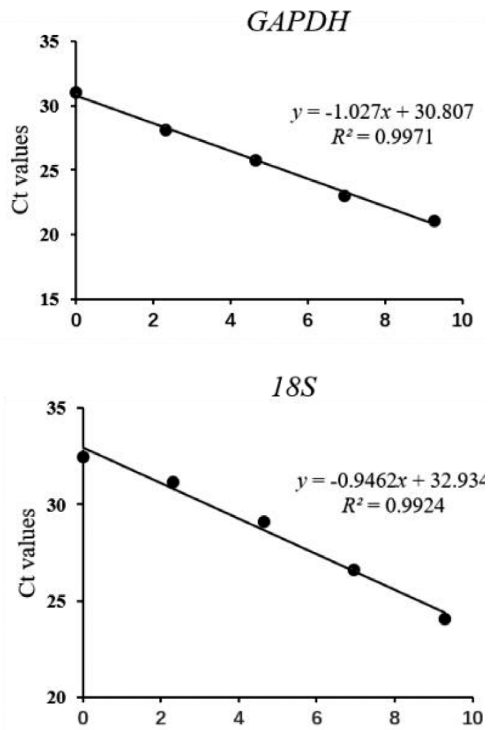

(B)
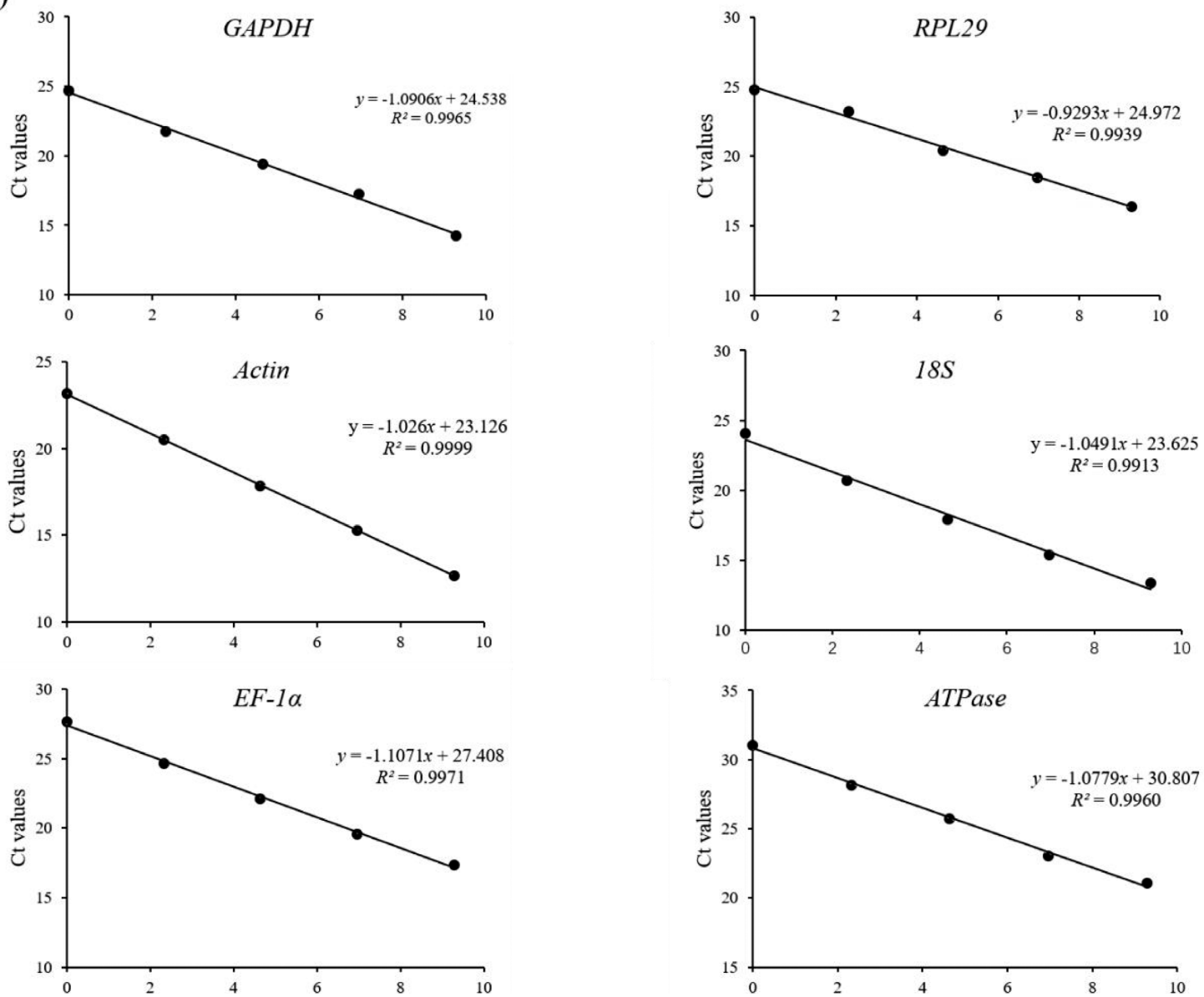
(C)

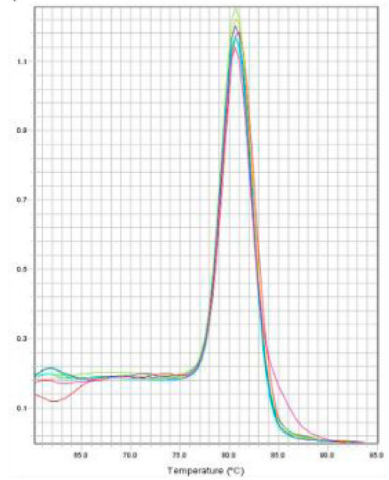

Actin

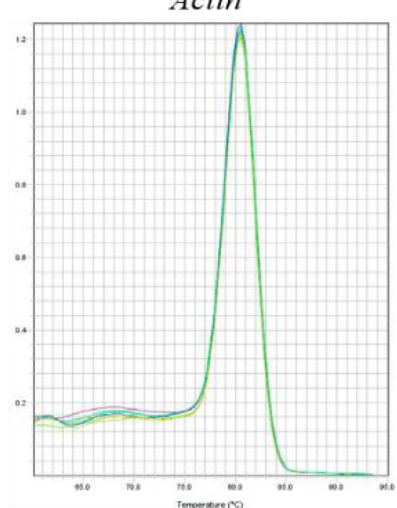

(D)

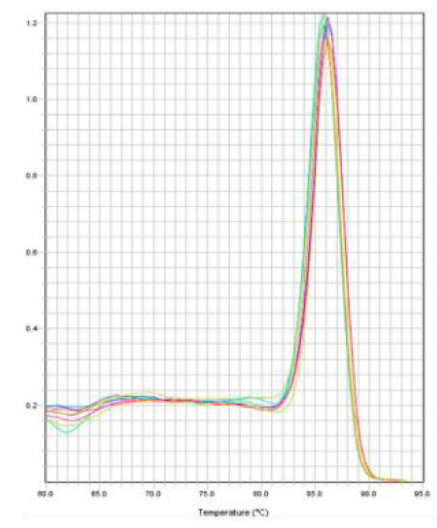

$18 S$

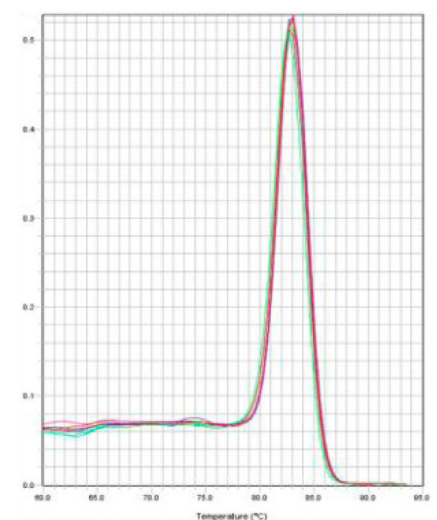

HSP70

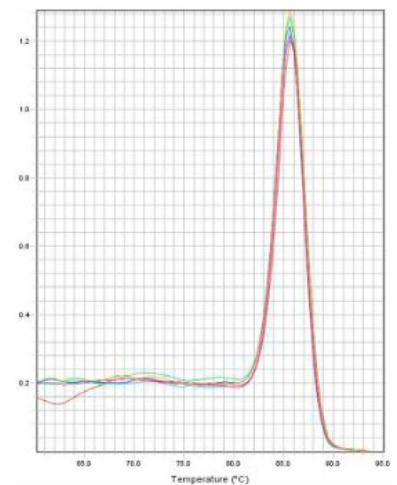

$18 S$

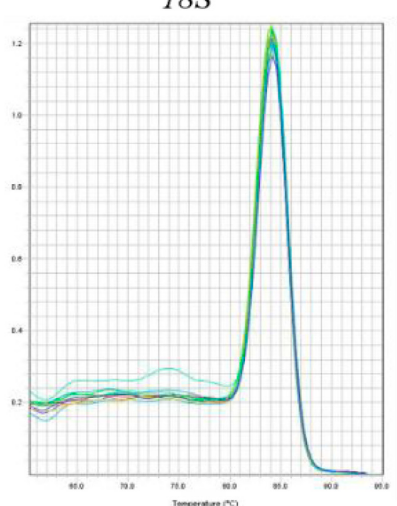

GAPDH

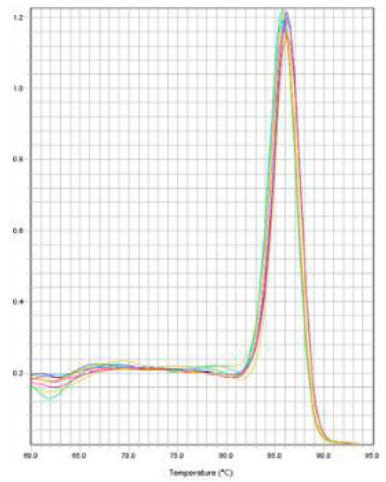

$E F-1 \alpha$

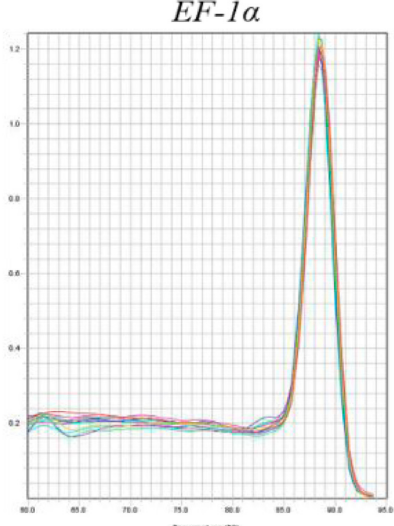

RPL29

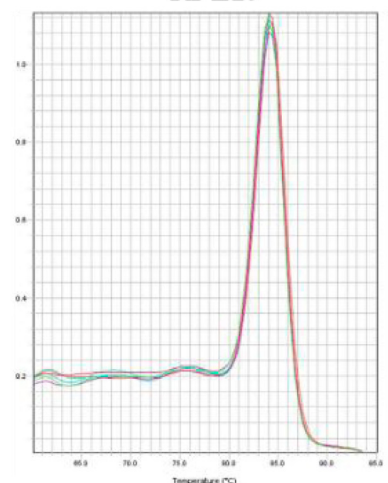

ATPase

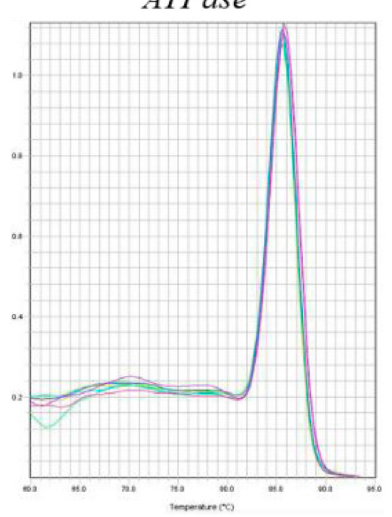

RPL29

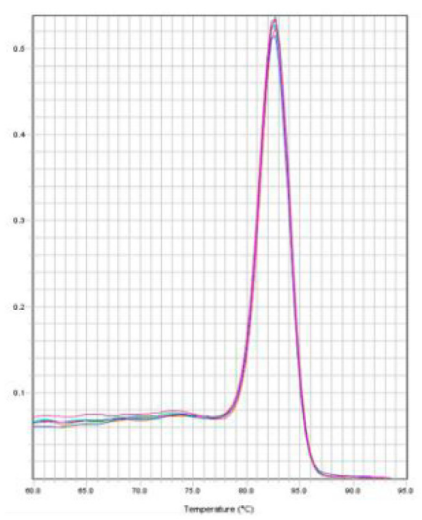

$E F-1 \alpha$

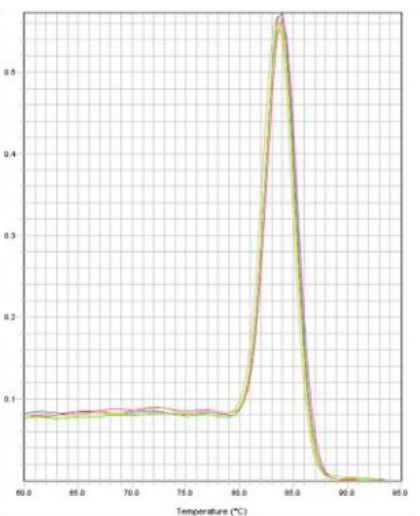

Actin

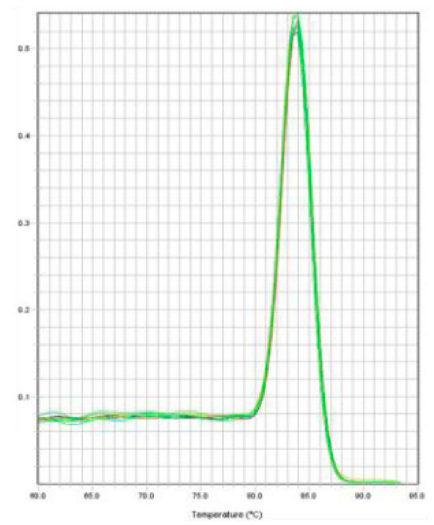

ATPase

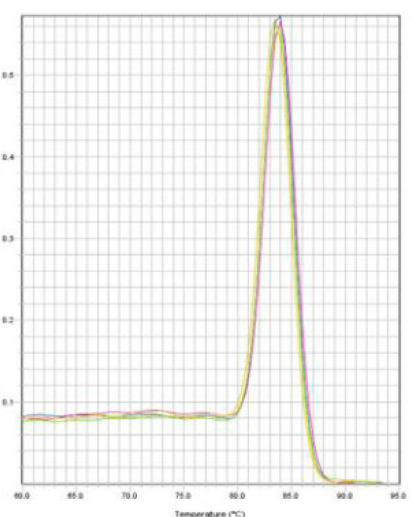

Fig. S3. Standard curves and melting curves of the reference genes. (A) Standard curves for gDNA templates; (B) Standard curves for cDNA templates; (C) Melting curves for gDNA templates and (D) Melting curves for cDNA templates. 